\title{
Pengembangan Game Board Sebagai Media dalam Layanan Bimbingan dan Konseling
}

Meriza Netaniel, Anastasia Catur O. P., Christina Andriyani K. \& Dwi Murtiningrum

Program Studi Bimbingan dan Konseling

Universitas Katolik Indonesia Atma Jaya

merizanetaniel70@gmail.com anastasiapratiwi59@gmail.com

christinaandriyani22@gmail.com dwimurtiningrum80@gmail.com

\begin{abstract}
Abstrak
Problematika dalam pendidikan, dengan semakin canggihnya dunia digital mengubah cara mengajar. Website merupakan salah satu media yang dapat diakses oleh semua orang dan menggunakan teknologi apa saja. Website ini menjadi salah satu solusi bagi guru untuk mengembangkan kreativitasnya dalam mengembangkan metode dan materi pembelajaran. Penelitian ini bertujuan untuk mengetahui efektivitas dalam memberikan inspirasi penggunaan website game board kepada calon guru BK yang akan digunakan pada proses belajar di sekolah. Sedangkan tujuan dari media yang kami buat adalah memberikan fasilitas pada guru BK dalam media pembelajaran kreativitas guru. Subjek yang diambil berdasarkan calon guru BK. Metode yang digunakan adalah research and development, dalam penelitian ini, peneliti langsung terjun ke lapangan untuk melakukan observasi, wawancara dan mendokumentasikan kegiatan serta memberikan kuesioner lewat g-form. Hasil penelitian menunjukkan bahwa ada (1) peningkatan ketertarikan guru menggunakan media pembelajaran sebagai sarana metode penyampaian materi yang efektif, (2) Penerapan website mudah dilakukan dan praktis, (3) Diakui mudah dalam pelaksanaan program BK. Selain itu juga ada faktor penghambat dalam mengembangkan kreativitas guru yaitu: membutuhkan biaya lebih dalam penerapannya dan membutuhkan waktu untuk membuat media.
\end{abstract}

Keywords: game board, media pembelajaran, penggunaan website, media bk, bimbingan konseling, teori pembelajaran

\section{Pendahuluan}

Dunia pendidikan merupakan salah satu sarana dalam mewujudkan tujuan negara, yaitu mencerdaskan kehidupan bangsa. Pendidikan memiliki peran penting untuk mewujudkan tujuan tersebut. Bagian-bagian yang terdapat dalam dunia pendidikan harus mempunyai kekuatan, berfungsi penuh, dan sesuai dengan kebutuhan peserta didik. Bagian 
penting dalam dunia pendidikan adalah guru dan metode pembelajaran yang digunakan. Guru berperan dalam mengatur dan mengkondisikan lingkungan belajar agar peserta didik dapat belajar dengan aman dan nyaman. Menurut Sigala (2016), keberhasilan belajar sangat ditentukan oleh metode pengajaran guru yang digunakan dalam menyampaikan materi pembelajaran yang sangat penting untuk diperhatikan dalam proses belajar mengajar.

Meningkatnya perkembangan teknologi di dunia berupa informasi dan hiburan berdampak kepada anak untuk menyukai tontonan seperti film, sinetron, main game, dan menjadikan internet sebagai guru mereka daripada mendengarkan pelajaran guru di kelas. Perkembangan teknologi sekarang menuntut guru untuk menciptakan pembelajaran yang menarik dan menghibur anak supaya tidak terkalahkan dengan teknologi informasi dan dunia hiburan yang semakin canggih. Sistem modern dalam pembelajaran menuntut siswa dapat berperan sebagai penyampaian pesan atau komunikator. Siswa tidak hanya duduk diam mendengarkan tetapi juga mengikuti serangkaian kegiatan pembelajaran secara aktif. Kegiatan pembelajaran harus menggunakan banyak media daripada ceramah. Meningkatkan keterampilan active learning dan proses.

Pelaksanaan tugas profesi guru harus dapat menjalankan proses pembelajaran aktif, dan menyenangkan. Hal yang harus dikuasai guru adalah bahan dan keterampilan dasar dalam mengajar, sehingga dapat menjalankan perannya secara optimal. Menurut Underwood (dalam Iriyani, 2008) penguasaan keterampilan dasar mengajar yang baik akan sangat mempengaruhi perilaku siswa dalam belajar. Kenyataan di lapangan menunjukkan, ada guruguru yang mengalami kesulitan dalam menerapkannya, hal ini terjadi karena tidak semua guru yang dididik di lembaga pendidikan dapat terlatih dengan baik. Mengenai kondisi guru yang diungkapkan Supriadi (dalam Iriyani, 2008) berbagai penelitian tentang guru diketahui bahwa tingkat penguasaan bahan ajar dan keterampilan dalam menggunakan metode mengajar yang inovatif masih kurang.

Saat ini, dunia BK dalam sekolah-sekolah hanya dilihat sebagai tempat untuk individu yang bermasalah, padahal ada banyak layanan yang dapat diberikan dalam upaya preventif sebelum masalah itu terjadi. Bimbingan konseling di sekolah kurang mempunyai tempat dan kesempatan untuk memberikan layanan bimbingan kelompok maupun klasikal. Terlihat juga dari beberapa mahasiswa yang menampilkan RPLnya tidak menggunakan media, hanya menggunakan lembar kerja. Siswa juga cenderung bosan ketika harus mengikuti kelas bimbingan konseling yang hanya berisi hal-hal atau cerita-cerita yang membosankan. Tidak ada sesuatu yang berbeda dengan cara mengajar mata pelajaran lainnya. Sehingga siswa 
dapat menganggap mata pelajaran bimbingan dan konseling sama dengan mata pelajaran yang lainnya yang kurang menarik perhatian.

Menurut Afgani \& Purwoko (2008), strategi pembelajaran berhubungan dengan cara menyampaikan materi pelajaran agar seseorang bisa belajar. Cara-cara yang dipilih harus direncanakan secara sistematis untuk mencapai hasil belajar yang optimal. Persiapan yang dilakukan adalah mendesain pembelajaran mulai dari menyiapkan materi, menemukan metode, mengajar dan menentukan alat fasilitas media. Persiapan terencana akan menghasilkan suatu proses pembelajaran yang bermakna bagi peserta didik. Bimbingan konseling menjadi salah satu bentuk pengajaran untuk membimbing dan memberikan layanan konseling di sekolah dalam upaya mewujudkan individu sehat. Sangat penting bagi guru BK untuk memberikan pembelajaran atau bimbingan dalam bentuk atau metode yang menarik dan tidak membosankan.

Sebuah artikel penelitian mengenai permainan papan budaya dikemukakan Robinson, dan Huckabee (dalam Triatuti, Akbar \& Irawan, 2017) alat permainan papan budaya dibuat untuk menguji pengetahuan dan berbagai disiplin ilmu kepada seseorang. Permainan ini memiliki beberapa ruang bermain yang mewakili bidang ilmu tertentu dan beberapa aturan yang meminta pemain mengklasifikasikan topik setiap kali pemain dapat menyelesaikan permasalahan pada kartu. Hal ini tentu membutuhkan waktu yang rerlatif lama. Peraturan pada permainan ini terlalu kompleks/kurang sederhana lebih cocok untuk anak dewasa.

Menurut Bartfay dan Bartfay (dalam Triatuti, Akbar \& Irawan, 2017) telah melakukan promosi kesehatan di sekolah-sekolah menggunakan media papan permainan. Hal ini menjadi topik yang paling mendasar bagi masyarakat di Kanada saat itu. Strategi pembelajaran yang dilakukan untuk memberikan kesadaran atas kesehatan tubuh pada siswa menjadi lebih efektif dan menyenangkan. Berdasarkan penelitian Priatama (dalam Triatuti, Akbar \& Irawan, 2017) mengembangkan media belajar Kimia di tingkat SMP dengan berbasis permainan monopoli memiliki potensi untuk dapat menanamkan nilai kejujuran, belajar berkompetisi, bekerjakeras, menghargai pendapat teman, dan saling percaya.

Maka, kami memberikan satu alternatif yang dapat digunakan atau dipelajari oleh guru dan calon guru BK untuk mempermudah dalam memberikan layanan di sekolah dalam metode yang menarik dan sesuai dengan karakteristik siswa jaman sekarang. Media menjadi pilihan untuk menciptakan suasana belajar yang menyenangkan, salah satunya media pembelajaran visual berupa games board. Games board adalah sebuah media pembelajaran yang sesuai dan mencangkup aspek kognitif (pengetahuan), afektif (perasaan), dan psikomotor (cara melakukan), karena dapat dimainkan lebih dari 2 orang atau berkelompok 
juga memiliki visual sesuai dengan pembelajar visual, selain itu games board juga bisa membantu dengan berdiskusi dengan tanya jawab sesuai dengan pembelajar auditory/audio, juga dapat membantu kinestetik dengan peragaan-peragaan yang ada.

Menurut Triyono \& Febriani (2018) penggunaan teknologi informasi yang produktif, kreatif dan inovatif akan didukung oleh persepsi yang positif oleh guru BK tentang pentingnya teknologi informasi dalam semua kegiatan BK di sekolah. Guru BK dituntut untuk menggali informasi terkait media pembelajaran.

Kelompok kami memfasilitasi guru dengan website pembuatan game board akan mempermudah guru dalam mendapatkan informasi dan menginspirasi cara menerapkan game board ke dalam pelajaran. Era saat ini, anak lebih menyukai dan tertarik dengan media pembelajaran yang terkesan menyenangkan dan banyak aktivitas yang dilakukan. Khususnya dalam dunia BK, bukan sekedar ceramah dari guru BK, melainkan ada kegiatan yang nantinya memberi makna dan membantu anak untuk dapat merefleksikan kehidupannya. Maka kami menyusun media game board sebagai salah satu bentuk model pembelajaran yang dapat diterapkan dalam pemberian layanan Bimbingan dan Konseling.

\section{Media Pembelajaran}

Menurut Malik ( dalam Sumiharsono 1994), media belajar adalah segala sesuatu yang dapat digunakan untuk menyalurkan pesan (bahan pembelajaran), sehingga dapat merangsang perhatian, minat, pikiran, dan perasaan pembelajar dalam kegiatan belajar untuk mencapai tujuan perkembangan tertentu. Media berfungsi untuk tujuan instruksi di mana informasi yang terdapat dalam media itu harus melibatkan siswa baik dalam benak atau mental maupun dalam bentuk aktivitas yang nyata sehingga pembelajaran terjadi. Sedangkan, media pembelajaran berfungsi untuk meningkatkan kualitas proses belajar belajar - mengajar. Media pembelajaran harus dapat memberikan pengalaman yang menyenangkan dan memenuhi kebutuhan perorangan siswa.

\section{Penggunaan Media Pembelajaran}

Heinich, Molenda, dan Russel (dalam Nurseto, 2011) dalam bukunya "Instructional Media and The New Technologies of Instructions" menyusun suatu model prosedural yang diberi nama akronim “ASSURE”. Model ASSURE ini dimaksudkan untuk menjamin penggunaan media pembelajaran yang efektif. 
Model yang diakronimkan dengan ASSURE itu meliputi 6 langkah dalam perencanaan sistematik untuk penggunaan media, yaitu:

1. Analyze Learner Characteristics (Identifikasi Kebutuhan dan Karakteristik Siswa)

Sebuah perencanaan media didasarkan atas kebutuhan (need), Salah satu indikator adanya kebutuhan yaitu kemampuan, keterampilan dan sikap siswa yang kita inginkan agar dapat dikuasai siswa.

2. $\quad$ State Objectives (Perumusan Tujuan)

Media pembelajaran harus dibuat sedemikian rupa sehingga akan membantu dan memudahkan siswa untuk mencapai tujuan pembelajaran.

3. Select, Modify, Or Design Materials (Merubah dan Merancang Media Pembelajaran)

Untuk membuat media yang tepat bagi kegiatan pembelajaran biasanya akan meliputi salah satu dari tiga kemungkinan yaitu a. Memilih media pembelajaran yang sudah tersedia, b.Merubah media yang sudah ada, dan c.Merancang pembuatan media yang baru.

\section{4. $\quad$ Utilize Materials (Perumusan Materi)}

Materi berkaitan dengan substansi isi pelajaran yang harus diberikan. Sebuah program media di dalamnya haruslah berisi materi yang harus dikuasai siswa.

5. Require Learner Response (Pelibatan Siswa)

Situasi belajar yang paling efektif adalah situasi belajar yang memberikan kesempatan siswa merespon dan terlibat dalam pembelajaran. Oleh karena itu siswa harus dilibatkan semaksimal mungkin dalam pemanfaatan penggunaan media.

\section{Evaluate (Evaluasi)}

Tujuan evaluasi media pembelajaran adalah untuk memilih media pembelajaran yang akan dipergunakan di kelas, untuk melihat prosedur penggunaan media, untuk memeriksa apakah tujuan penggunaan media tersebut telah tercapai, menilai kemampuan guru menggunakan media, memberikan informasi untuk kepentingan administrasi, dan untuk memperbaiki media itu sendiri.

\section{Media Website}

Pembelajaran yang menggunakan media komputer sangat efektif jika dapat dirancang dan digunakan dalam proses pembelajaran yang terpadu terlebih bertujuan untuk memfasilitasi guru BK yang akan memperpanjang pengetahuan ke peserta didik. Penyampaian materi belajar berbentuk game board melalui teknologi komputer sangat penting, dengan syarat bahwa perencanaan pembelajaran harus dapat merancang program secara terstruktur dan 
mudah dimengerti oleh para penggunanya dalam hal ini guru BK, karena menurut Kemp \& Dayton (dalam Arsyad), media mempunyai manfaat sebagai media yang dapat menarik perhatian, memberikan pengalaman kepada siswa (guru BK) untuk berinteraksi langsung sehingga memberikan sikap positif kepada siswa untuk belajar secara mandiri dengan guru sebagai fasilitator. Ada lima faktor yang perlu dipertimbangkan dalam pemilihan media yang akan anda gunakan untuk mengembangkan materi pembelajaran (Dick \& Carey, 1978 : 128 129), yaitu : 1) Jenis pembelajaran, 2) Ketersediaan media, 3) Kemampuan designer, 4) Keluwesan (flexibility), Daya tahan (Durability), dan Kemudahan (convenience) materi dalam suatu media, dan 5) Efektifitas biaya. Dengan memperhatikan kelima faktor tersebut, maka materi program BK seperti self-esteem dan empathy merupakan materi pembelajaran yang memerlukan pemahaman menggunakan kreativitas dan tim menggunakan media game board melalui template yang diberikan pada website.

Pada penelitian ini, pembelajaran dilakukan secara mandiri oleh calon guru BK dan guru BK dengan memberi kesempatan calon guru BK untuk menggunakan fasilitas web serta materi. Materi ajar yang disediakan untuk memfasilitasi guru BK dan Calon guru bk antara lain adalah self-esteem sunglasses, let's build empathy dan my coping tools spinner. Ketiga permainan ini memiliki unsur pendidikan Bimbingan Konseling yang dapat diberikan sebagai pembelajaran karakter kreatif pada peserta didik. Karena media website ini akan digunakan sebagai sumber pembelajaran makan harus memiliki beberapa kriteria seperti: harus memenuhi kejelasan materi dan tujuan belajar, dikemas menggunakan desain yang menarik, dapat disampaikan melalui media, dipat diunduh secara gratis dan mudah, dan disertai program tutorial. Karena fasilitas yang dipakai menggunakan sistem elektronik, maka aktivitas pembelajaran oleh guru dan calon guru BK menggunakan komputer ataupun gawai yang terkoneksi internet.

\section{Game Board}

Permainan merupakan sesuatu yang menarik bagi anak. Melalui permainan, anak mendapatkan kesenangan. Sesuatu yang dipelajari anak melalui kegiatan permainan ini akan disimpan baik di dalam pikirannya dan akan dipadukan menjadi satu kesatuan yang utuh bersama pengalaman - pengalaman yang lain. Bermain termasuk aktivitas yang tidak dapat dipisahkan dari anak-anak. Akan tetapi, kita tidak mungkin membiarkan anak - anak hanya tenggelam dalam permainan sepanjang waktu tanpa adanya unsur pendidikan di dalamnya. 
Kita harus memikirkan cara agar anak dapat terus bermain, tetapi mereka juga mendapat pelajaran dari permainan tersebut.

Jenis permainan yang banyak diminati anak adalah permainan dalam bentuk papan. Jenis permainan dalam bentuk papan yang memungkinkan untuk dijadikan sebagai media dalam meningkat kan motivasi belajar siswa antara lain papan permainan ular tangga, papan permainan logico, dan papan permainan monopoli. Namun dalam penelitian ini, peneliti membuat permainan papan dengan topik Self-Esteem Sunglasses, Let's Build Empathy, dan My Coping Tools Spinner.

Untuk kepentingan pembelajaran, maka media ini dapat dibuat sendiri oleh guru dengan menyusun tujuan dan materi pembelajaran berdasarkan kurikulum yang berlaku. Kotak kotak kecil pada papan permainan diganti dengan gambar yang dimodifikasi sebaik mungkin menggunakan gambar - gambar yang variatif dan menarik bagi siswa. Selain itu, untuk mengukur ketercapaian tujuan pembelajaran, guru membuat kartu pertanyaan yang memuat pertanyaan dan jawaban yang sesuai. Kita dapat membuat media dari bahan kardus bekas atau dari kertas karton yang dinilai ekonomisnya murah dan mudah didapat. Aturan permainan dapat dimodifikasi agar siswa mendapat pengalaman yang bermakna dalam memainkannya.

Berkaitan dengan penggunaan media papan permainan sebagai salah satu media dalam pembelajaran, Akbar (2013:117) mengemukakan prinsip - prinsip dalam memilih media. Prinsip tersebut yaitu (1) sesuai dengan tujuan pembelajaran pada kurikulum yang berlaku; (2) sesuai dengan karakteristik siswa; (3) pemanfaatannya efektif dan efisien; (4) dapat mengembangkan aktivitas siswa; serta (5) mampu mengembangkan suasana belajar yang menyenangkan. Dengan memperhatikan prinsip tersebut, diharapkan media mampu meningkatkan kualitas pembelajaran. Siswa tidak hanya sekedar bermain, namun siswa telah belajar dengan dibekali nilai karakter positif yang dapat diterapkan dalam kehidupan sehari hari. Konsep permainan dalam bentuk papan dilakukan secara berkelompok/kooperatif, sehingga mengajak siswa untuk mampu bekerjasama dengan siswa lainnya. Pembelajaran secara kooperatif ini mampu membangun nilai - nilai/karakter positif pada diri siswa. Nilai karakter positif yang terkandung di dalam papan permainan antara lain mengembangkan sikap empati terhadap teman, kerjasama, kebersamaan/kekompakan, disiplin, jujur, menghargai orang lain, serta melatih tanggung jawab. 


\section{Metode Penelitian}

Metode penelitian yang digunakan dalam penelitian ini merupakan penelitian pengembangan atau Research and Development $(R \& D)$. Research and Development adalah model penelitian yang digunakan untuk menghasilkan produk tertentu dan menguji keefektifan produk (Sugiyono, 2012). Produk yang dimasksud dalam penelitian ini adalah pemberian fasilitas game board pada media website dengan tujuan memfasilitasi guru BK nantinya untuk meningkatkan kreativitas mengajar pada peserta didik di jenjang Sekolah Dasar.

Uji coba terbatas dilaksanakan di Unika Atma Jaya Jakarta pada angkatan 2019 di tanggal 12 Maret 2020. Uji coba lapangan luas dilaksanakan pada calon guru BK yang berkuliah di tingkat akhir serta guru BK di sekolah di Jakarta dari tanggal 17 - 20 Maret 2020 . Subjek uji coba dipilih secara random dan dibagi menjadi dua yaitu subjek uji coba terbatas dan uji coba lapangan luas. Subjek uji coba terbatas menggunakan mahasiswa BK Unika Atma Jaya angkatan 2019 dengan jumlah 5 mahasiswa sebagai representasi dari calon guru BK. Subjek uji coba lapangan luas menggunakan mahasiswa BK tingkat akhir dan guru BK yang telah bekerja di sekolah dengan jumlah 20 orang.

Model pengembangan yang digunakan dalam penelitian ini yaitu mengintegrasikan model 4D dengan mode pengembangan instrumen non tes. Model pengembangan 4D memiliki langkahlangkah (1) define, (2) design, (3) develop, (4) disseminate, sedangkan model pengembangan produk website memiliki 7 langkah sebagai berikut: (1) Pengembangan ide, (2) mengidentifikasi produk, (3) Merancang prototipe produk, (4) Membuat template produk, (5) melakukan uji coba terbatas, (6) menelaah produk, (7) melakukan uji coba pada lapangan luas, (8) menafsirkan hasil pengukuran produk.

Pertama

Rancangan pendahuluan yaitu proses pengembangan ide-ide, baik dari end user ataupun pengalaman pribadi. Terdiri atas 3 tahapan yaitu analisis kebutuhan peserta didik, analisis kebutuhan guru, dan analisis media yang terkait dengan materi kebutuhan dari peserta didik. Hal ini dilakukan untuk mengumpulkan informasi, menganalisis kebutuhan, review jurnal yang berkaitan dan menganalisis kebutuhan peserta didik, serta mengidentifikasi faktor-faktor yang menimbulkan permasalahan sehingga diperlukan media yang dapat memfasilitasi guru BK. Melalui hal tersebut diperlukan pengembangan model media ataupun materi baru. 
Pendahuluan pada kegiatan ini meliputi studi lapangan dan review jurnal terkait. Studi lapangan menggunakan metode wawancara dengan guru BK dan calon guru BK yang dikenal dan ada disekitar kampus. Review jurnal dilakukan dengan mengumpulkan beberapa jurnal terkait dan buku - buku yang relevan dengan pengembangan proyek untuk memfasilitasi guru BK dalam menyajikan materi dengan cara yang kreatif, pada beberapa materi seperti self esteem, dan empathy.

\section{Kedua}

Mengidentifikasi produk. Pada tahap ini meliputi kegiatan memilih media dan masalah . Pada tahap ini meliputi kegiatan memilih bentuk dan menyortir ide terbaik, untuk dapat mengembangkan sebuah ide menjadi sebuah produk baru, ide-ide tersebut harus memenuhi beberapa pengujian analisis seperti: potensi pengguna, kreatifitas produk, kesesuaian kebutuhan, dan terutama produk tersebut memungkinkan untuk diproduksi, untuk spesifikasi desain produk dibutuhkan informasi mengenai: media apa yang akan digunakan, data sebelum menentukan media dan masalah, tata cara pengujian tampilan produk teknologi pendidikan, dan hal-hal yang dibutuhkan.

\section{Ketiga}

Merancang prototipe produk, dalam hal ini masih berupa ide dan percontohan produk yang serupa, sebelum di jadikan hasil akhir. Tim membuat produk didasarkan pada poin - poin yang sudah dijelaskan di tahap kedua.

\section{Keempat}

Membuat sejumlah prototipe proyek dalam hal ini adalah template game board yang diperuntukan untuk memfasilitasi guru khususnya guru BK. Prototipe yang dibuat berdasarkan dengan kebutuhan materi yang dikaitkan dengan penyebab masalah peserta didik seperti self-esteem dan empathy.

\section{Kelima}

Melakukan uji coba terbatas, pengujian dalam scope kecil yaitu 5 orang mahasiswa calon guru BK. Tujuannya untuk: Mengumpulkan data kuantitatif tanggapan user mengenai produk tersebut. Kami menggunakan observasi dan wawancara sebagai alat untuk mengambil data. Memperlihatkan penampilan dan juga prosedur teknis yang digunakan serta contoh fisik dari 
template game board yang dapat mereka gunakan. Melakukan perubahan ataupun penyempurnaan pada produk sesuai dengan hasil pengujian di scope kecil yang telah dilakukan.

Keenam

Menelaah produk dan melakukan penyempurnaan produksi kembali sesuai dengan feedback yang telah dimiliki, dan hasil dari feedback yang didapatkan melalui proses wawancara pada scope kecil dan berdasarkan masukan review pada saat kelas teknologi pendidikan. Beberapa hal yang kami tambahkan antara lain menambah informasi mengenai cara bermain, menambah informasi mengenai materi.

Ketujuh

Melakukan uji coba pada lapangan luas, setelah mendapatkan saran dan masukan dari Dosen dan teman-teman, tim melakukan perbaikan-perbaikan sesuai dengan masukan yang ada. Selanjutnya produk disempurnakan dan dipublish di website yang sudah kami buat sebelumnya. Uji coba ini bertujuan untuk mengetahui apakah media online website dengan materi game board dapat bermanfaat bagi guru khususnya guru BK. Hasil uji coba di lapangan dianalisis untuk melihat kebermanfaatan dari website dengan game board sebagai materi untuk memfasilitasi guru BK dalam menciptakan pembelajaran yang kreatif.

Kedelapan

Menafsirkan hasil pengukuran produk, hasil pengukuran dari penyebaran angket saat uji coba di lapangan luas. Data yang di peroleh menggambarkan keberhasilan dan kebermanfaatan dari proyek dan materi ajar yang tim buat pada media website.

\section{HASIL PENELITIAN DAN PEMBAHASAN}

\section{A. Hasil Penelitian}

Pengembangan media game board diawali dengan tahap analisis kebutuhan melalui literatur, dan melihat langsung proses kegiatan layanan Bimbingan dan Konseling yang membutuhkan suasana baru agar lebih menarik dan tetap dapat mencapai tujuan dalam proses layanan Bimbingan dan Konseling. Melalui fungsi layanan BK, seharusnya 
ada banyak hal yang dapat dilakukan dengan cara yang lebih menarik. Maka kami melakukan uji coba terlebih dahulu kepada 5 mahasiswa BK yang nantinya akan menjalankan profesi dalam dunia Bimbingan dan Konseling. Dari lima mahasiswa tersebut, media ini mendapatkan banyak masukan untuk dikembangkan lebih baik lagi.

Setelah melalui proses wawancara dan observasi, dilanjutkan dengan proses tindak lanjut, yaitu memperbaiki media website yang berisi game board berdasarkan pada masukan dari calon guru BK. Setelah semua proses tindak lanjut dilalui, maka media ini siap untuk dibagkan dalam kelompok yang lebih besar jumlahnya.

Media Website yang digunakan adalah wix.adi yang didalamnya terdapat tiga jenis game board dan juga link menuju file drive yang dapat langsung di print dan digunakan oleh guru BK atau konselor

Kegiatan uji coba dilakukan melalui chat siaran yang dibagikan melalui pesan whatsapp. Isi dari pesan siaran tersebut berupa penjelasan singkat dari media pembelajaran yang dibuat, kemudian link website dan link g-form yang harus diisi oleh responden setelah melihat website game board. Dari kegiatan uji coba, didapatkan responden sebanyak 25 responden yang saat ini bekerja sebagai guru BK, dan beberapa sedang belajar di program studi Bimbingan dan Konseling. Berdasarkan hasil uji coba yang telah dilakukan, didapatkan data sebagai berikut, 25 orang mengatakan bahwa media ini menarik dan mempunyai banyak kelebihan. Namun masih ada kekurangan dan juga masih ada masukan / saran yang diungkapkan untuk mengembangkan lagi website media game board ini.

\section{B. Pembahasan}

Berdasarkan hasil uji coba yang dilakukan terdapat kelebihan dan kekurangan dari web media belajar menggunakan media game board yang dapat disimpulkan sebagai berikut :

Kelebihan media game board:

a. Memudahkan dalam pelaksanaan program BK

b. Dapat melatih kemampuan kognitif anak

c. Media yang menyenangkan

d. Mudah untuk diaplikasikan 
e. Dilengkapi dengan gambar dan materi

f. Praktis dan tujuannya jelas.

g. Dapat disesuaikan dengan jenjang usia yang menjadi sasaran.

h. Menyediakan bahan yang dapat langsung di print.

Selain kelebihan, media ini juga mempunyai kekurangan, yaitu :

a. Menuntut adanya kemampuan mengakses website.

b. Membutuhkan biaya lebih untuk mencetak bahan.

c. Membutuhkan waktu yang lebih lama saat bermain game.

Media game board yang dibuat memang membutuhkan keterampilan dalam penggunaan teknologi, sehingga pengguna tidak mengalami kebingungan. Jika akan menggunakan media ini, guru BK memang harus mencetak sendiri bahan untuk bermain game yang telah tersedia. Selain itu, waktu yang dibutuhkan cenderung lebih lama. Jika ini akan diterapkan di sekolah, guru BK harus mampu mengatur waktu atau jam pelajaran BK sehingga tujuan dari game dapat tercapai. Karena jika ini dilakukan dalam bimbingan klasikal, maka guru BK harus dapat menggali dari banyak siswa untuk mendapat kesimpulan. Maka game ini lebih cocok untuk konseling kelompok atau individual artinya dengan jumlah sasaran lebih sedikit. Namun jika untuk klasikal juga tetap bisa digunakan selama guru BK dapat mengatur waktu, dalam menyusun kegiatan bimbingan klasikal.

\section{Kesimpulan}

Berdasarkan hasil penelitian yang telah dilakukan kepada calon guru BK, maka dapat disimpulkan bahwa Media games board dinilai sangat efektif dan menarik. Calon guru BK terinspirasi dengan cara menyajikan materi menggunakan game board. Penggunaan website yang mudah dan langkah-langkah pembuatannya mempermudah untuk diikuti. Metode ini mempunyai banyak manfaat, dan mudah untuk diaplikasikan. Website yang telah dibuat mudah diakses melalui hp atau laptop sehingga mempermudah penggunanya.

\section{Saran}


Sebaiknya media ini segera disebarluaskan, sehingga lebih banyak yang mengetahui metode ini. Mengupload gambar games yang dapat langsung di print. Memberikan penjelasan tentang cara untuk menyiapkan games. Menggunakan bahasa yang mudah dimengerti. Pada pengembangan website, sebaiknya ditambah games yang lain. Menggunakan games yang mudah didapatkan

\section{Daftar Pustaka}

Afgani, M. W., Darmawijoyo, D., \& Purwoko, P. (2008). Pengembangan media website pembelajaran materi program linear untuk siswa sekolah menengah atas. Jurnal pendidikan matematika, 2(2). Doi: https://doi.org/10.22342/jpm.2.2.302.

Dick, W and Carey, L.(1978).The Systematic Design of Instruction. United States of America:Scott, Foresman and Company.

Efendi, M. (2013). Pengembangan Media Blog dalam Layanan Informasi Bimbingan dan Konseling. Jurnal BK: UNESA, 1 (1), 1-20. Doi:unesa.ac.id/index.php/jurnal-bkunesa/article/view/1951

Hazrati, R,. Wirda, \&Hanim. (2016) .Pengaruh Media Dalam Layanan Bimbingan Kelompok Terhadap Pengaturan Diri Siswa Kelas XI di SMAN 56 Jakarta. Insight: Jurnal Bimbingan dan Konseling. 5(1). 94-99. Doi: https://doi.org/10.21009/INSIGHT.051.14

Iriyani, D. (2008). Pengembangan Supervisi Klinis untuk meningkatkan keterampilan dasar mengajar $\quad$ guru. Jurnal 285-285. Doi:http://repository.ut.ac.id/id/eprint/7398

Nurhidayan, R, W., Lutfi, \& Tutut, N. (2013).Uji Coba Media Permainan Berbasis Komputer Pada Pembelajaran Bahan Tambahan Makanan Untuk Siswa SMP. Pensa E-Jurnal: $\begin{array}{llll}\text { Pendidikan } & \text { Sains. } & \text { 1(2). } & \text { 235-239. }\end{array}$ https://jurnalmahasiswa.unesa.ac.id/index.php/pensa/article/view/2679/1608

Nurseto, T. (2011). Membuat media pembelajaran yang menarik. Jurnal Ekonomi dan pendidikan, 8(1).19-35. Doi : https://doi.org/10.21831/jep.v8i1.706 
Nusantara, D. B., \& Irawan, A. H. (2012). Perancangan Boardgame Sebagai Media Pembelajaran Ilmu Pengetahuan Alam Untuk Anak SD Kelas 1. Jurnal Sains dan Seni ITS, 1(1), F22-F27. Doi: http://dx.doi.org/10.12962/j23373520.v1i1.503

Prasetiawan, Hardi. (2017). Optimalisasi Multimedia Dalam Layanan Bimbingan dan Konseling.Jurnal PSBK : Prosiding Seminar Bimbingan dan Konseling. 1(1). 199-204. Doi : http://pasca.um.ac.id/conferences/index.php/snbk

Sigala, L. I. S. A. (2016). Hubungan Persepsi Siswa Tentang Cara Mengajar Guru dengan Motivasi Belajar Siswa yang Pernah Mengikuti Remedial Kimia di SMA ITCI Penajam Paser Utara (Khusus Siswa-Siswi Ilmu Pengetahuan Alam). Psikoborneo, 4(3), 462-469. Doi:http://ejournal.psikologi.fisip-unmul.ac.id/site/wpcontent/uploads/2016/09/Jurnal\%20LISA\%20-\%200NLINE\%20(09-26-16-10-42$\underline{35) . p d f}$

Sukmasari, V. P., \& Rosana, D. (2017). Pengembangan penilaian proyek pembelajaran IPA berbasis discovery learning untuk mengukur keterampilan pemecahan masalah. Jurnal Inovasi Pendidikan IPA, 3(1), 101-110. Doi: https://doi.org/10.21831/jipi.v3i1.10468

Sumiarsono, M.R.(2017). Media Pembelajaran. Jawa Timur. Cv. Pustaka Abadi.

Susanto, E. (2012). Penggunaan Media Dalam Proses Bimbingan Kelompok Untuk Mengembangkan Kreativitas Pada Siswa SMA Negeri 10 Bandar Lampung Tahun Ajaran 2007-2008. Guidena: Jurnal Ilmu Pendidikan, Psikologi, Bimbingan Dan Konseling. 2(1).357-645doi: https://doi.org/10.24127/gdn.v2i1.357

Triastuti, D. Akbar, S., \& Irawan, E. (2016). Penggunaan Media Papan Permainan untuk Meningkatkan Motivasi Belajar Siswa di Sekolah Dasar. Seminar Nasional Pengembangan Profesionalisme Pendidik untuk Membangun Karakter Anak, (2). 257264. Doi : http://pasca.um.ac.id/conferences/index.php/gtk/article/view/273

Triastuti, D., \& Irawan, E. B. (2017). Pengembangan Media Papan Permainan Panjat Pinang. Jurnal Pendidikan: Teori, Penelitian, dan Pengembangan, 2(10), 1344-1350. Doi:http://dx.doi.org/10.17977/jptpp.v2i10.10073 
Triyono, T., \& Febriani, R. D. (2018). Pentingnya Pemanfaatan Teknologi Informasi oleh Guru Bimbingan dan Konseling. JUANG: Jurnal Wahana Konseling, 1(2), 74-83. Doi: http://dx.doi.org/10.31851/juang.v1i2.2092

Vidya, P. Dadan, R. (2017). Pengembangan Proyek Pembelajaran IPA Berbasis Discovery Learning untuk Mengukur Keterampilan Pemecahan Masalah. Jurnal Inovasi Pendidikan IPA, 3(1). Doi : https://journal.uny.ac.id/index.php/jipi/article/view/10468 